\title{
Unconventional monetary policies and the credit market
}

\author{
Jose Olmo* (J.B.Olmo@soton.ac.uk) \\ Department of Economics, University of Southampton \\ Marcos SAnso-Navarro (marcossn@unizar.es) \\ Departamento de Análisis Económico, Universidad de Zaragoza
}

June 2017

\begin{abstract}
We propose a theoretical model based on the bank lending channel to assess the ability of lending facilities and swap programmes to affect the credit interest rate. The model predicts the success of both unconventional monetary measures in reducing the credit interest rate under very general conditions. The comparison between measures reveals the outperformance of lending facilities over swap programmes if i) the risk premium on the interbank money market is sizeable and the yield on government bonds is low, ii) the share of bank lending obtained from the central bank is below some specific threshold, iii) the interest rate offered by the central bank on excess reserves is high, and iv) the default rate on loans is high. The quantitative assessment of the model with real data confirms the appropriate response of the Federal Reserve in recent crisis episodes but sheds some doubts on the European Central Bank intervention.
\end{abstract}

Keywords: Bank profit maximization, credit interest rate, optimal credit supply, unconventional monetary policy.

JEL codes: E41, E50, G21.

\footnotetext{
${ }^{*}$ Corresponding author. Address: School of Social Sciences, Department of Economics, University of Southampton, Room 3015, Bld 58 (Murray Bld), Highfield Campus, Southampton, SO17 1BJ, UK. Tel: +44(0)238059 2537. Fax: +44(0)2380593858.
} 


\section{Introduction}

In the face of severe dislocations in financial markets and profound declines in economic activity, monetary authorities have taken extraordinary measures beyond lowering shortterm policy rates using the size and structure of their balance sheets (Borio and Disyatat, 2010; Durré and Pill, 2012). These alternative measures have been adopted for two main reasons. First, nominal short-term interest rates reached the lower bound during this period in many countries, losing their ability to stimulate the economy (Reifschneider and Williams, 2000). Second, disruptions in the financial system generated large losses and affected the liquidity and solvency of both banks and borrowers.

One noteworthy example of an unconventional monetary policy (UMP, hereafter) is the Maturity Extension Program carried out by the Federal Reserve (FED) and consisting of sterilized operations, buying long-term Treasuries and, simultaneously, selling some of the short-term issues. The FED also followed a large-scale asset purchase (LSAP) programme of mortgage-backed securities with the aim of increasing market liquidity and reducing mortgage interest rates (credit easing). Nevertheless, the most popular LSAP across monetary authorities in the recent crisis has been the so-called quantitative easing (QE), based on the creation of money to buy assets. While the FED bought Treasuries, agency debt and agency-backed mortgage securities, the Bank of England purchased government bonds from the non-bank private sector. Although the main objective was in both cases to affect yields on assets, the European Central Bank (ECB) used QE to mitigate liquidity problems within the banking system. More specifically, it carried out repurchase agreements providing long-term loans in exchange for bank loans and non-government bonds.

The effectiveness of these UMPs which aim to restore the functioning of the financial system has been an object of debate since their inception (Joyce et al., 2012). Nevertheless, their influence on credit markets and the real economy are not well understood yet. Lenza et al. (2010) argue that QE mainly affected interest rates - in particular, money market spreads - rather than only generating quantitative effects in the money supply. These 
authors also discuss alternative channels through which UMPs can be transmitted into the economy. In this respect, non-standard measures can influence bank lending through the expansion of the monetary base, the level of the overnight interest rate determining the access to liquidity in the money market or the expectations about the path of future policy decisions that affect the slope of the money market yield curve. It is worth noting that despite the success of these measures in restoring stability to the financial sector and the flow of credit to financial markets through the above-mentioned mechanisms borrowing costs have not fallen to levels commensurate with the magnitude of the measures implemented by the monetary authorities. Cukierman (2013) also notes the importance of this anomaly and suggests that it is yet to be determined whether the transmission of monetary policy to commercial banks' lending rates differs between normal times and periods of distress.

The aim of this paper is to analyze this anomaly in detail. In particular, we aim to study the success of the main UMP measures proposed by policy makers for restoring the provision of credit by commercial banks. In order to do this, we investigate the effect of two major UMP measures - lending facilities and swap programmes - on the credit interest rate and its spread with the short-term policy rate. We consider the bank lending channel as their main transmission mechanism to credit interest rates. More specifically, we propose a model in which banks maximize a static profit function constructed from their balance sheets. In our theoretical framework, the main decision variable of commercial banks is the optimal amount of lending to the nonfinancial sector. Banks' balance sheets incorporate realistic features of their assets and liabilities sides. On the asset side, we consider the possibility for commercial banks to set aside funds with the central bank as excess reserves earning an interest rate greater than the interest rate offered to minimum reserves. On the liability side, we contemplate the existence of an interbank money market in which commercial banks borrow and lend funds at a given interest rate, and also the existence of deposits from customers.

In this model, the credit interest rate is obtained from equilibrium conditions. Therefore, the demand of loans by the non-financial sector is assumed to depend on economic activity 
(output). The supply side of the credit market is given by the aggregate supply of loans by commercial banks. This quantity is obtained as the sum over all commercial banks of their optimal loan supply, which is obtained from their profit maximization behavior. As a consequence, we incorporate the extent of competition in the loan market as an additional variable with an effect on the equilibrium credit interest rate.

We explore the equilibrium credit interest rate under three different scenarios: a baseline characterized by the inaction of the central bank, the creation of lending facilities and the implementation of swap programmes. First, we compare each UMP against the baseline model given by inaction of the central bank. In this case, our model predicts that lending facilities are appropriate measures for reducing the credit interest rate when the assets held by banks as collateral lose their value and when the risk premium on the interbank money market is high. Otherwise, the implementation of lending facilities may raise borrowing costs for the non-financial sector more than in the baseline case. The comparison of swap programmes with the baseline model predicts the success of swap programmes in reducing the credit interest rate with central bank's inaction if the return offered by government bonds to commercial banks as a result of swap programmes is higher than the return provided by the collateral assets on defaulted loans. Second, we compare the performance between lending facilities and swap programmes. We show that lending facilities outperform swap programmes when i) the risk premium on the interbank money market is sizeable and the yield on government bonds is low, ii) the share of bank lending obtained from the central bank is not very large ${ }^{1}$, iii) the interest rate offered by the central bank on excess reserves is high, and iv) the default rate on loans is high. Otherwise swap programmes are more successful than lending facilities in reducing the credit interest rate.

We also carry out a quantitative assessment of the proposed model with real data from the United States (US) and the euro area (EA). In both cases the simulated equilibrium outcomes provide ample support for the implementation of swap programmes to reduce the credit interest rate with respect to the baseline scenario. This exercise raises, however,

\footnotetext{
${ }^{1}$ More specifically, we observe that the greater the reliance of the banking sector on central bank lending during normal periods the more difficult it becomes for lending facilities to reduce the credit interest rate.
} 
important concerns on the success of lending facilities. In particular, we observe that in market conditions such as those in the EA, lending facilities would only be able to reduce the credit interest rate beyond that in the baseline model if the spread between the interbank money market and the official interest rate is larger than the return obtained from collateral assets, the reward on excess reserves and the amount of credit borrowed from the central bank.

The present paper is related to Brei et al. (2013) who analyze the success of rescue measures adopted by the monetary authorities during the global financial crisis of 2008-2009 in sustaining bank lending supply. Their empirical study for a sample of large international banks concludes that bank recapitalisations may not translate into greater credit supply until commercial banks' balance sheets are sufficiently strengthened. Christiano and Ikeda (2011) also focus on the bank-lending channel to assess the impact of UMPs on economic conditions. In particular, these authors aim to determine which asset market program, and at what scale, should be undertaken. Using arguments based on moral hazard and adverse selection under the presence of financial frictions, these authors explore different channels by which the effects of UMPs might have occured. Related studies considering the effects of government asset purchases on different aspects of the economy are Moore (2009) and Kiyotaki and Moore (2012). Our work is also related to Fungáková et al. (2014), that analyse the effect of market competition on determining the success of the transmission of monetary policy to commercial banks. The quantitative assessment carried out in the present paper builds on Cukierman (2013), who compares the policies implemented by the ECB and the FED during the global financial crisis as well as the behavior of EA and US banks.

The rest of the article is structured as follows. Section 2 introduces a partial equilibrium model for the credit market that takes into account the balance sheet structure of commercial banks, the probability of loan default and the existence of an interbank money market. Building on this model, Section 3 analyzes the effects of the implementation of UMPs on the credit interest rate in equilibrium and determines the influence of excess reserves on 
it. Section 4 presents a simulation exercise that illustrates the functioning of the model in different scenarios. Section 5 concludes.

\section{A model for the credit market}

In this section we propose a model in which banks maximize a static profit function based on an optimal composition of their balance sheets. The main decision variable by commercial banks is the optimal amount of lending to the nonfinancial sector. Banks' balance sheets incorporate realistic features of their assets and liabilities. Thus, on the asset side, we consider the possibility for commercial banks to set aside funds with the central bank as excess reserves earning an interest rate greater than the interest rate offered to central bank's minimum reserves. On the liability side, we contemplate the existence of an interbank money market, where funds from commercial banks with an excess of deposits from customers are channelled to banks with a shortage. Following traditional reserve management models such as Orr and Mellon (1961), Niehans (1978) and Baltensperger (1980), customer deposits are exogenous and depend on stochastic flows.

The competition faced by commercial banks is determined by the number of banks $N$ in the system. In fact, the extent of competition is one of the drivers of the credit interest rate in equilibrium. The rest of interest rates in the banks' profit maximization problem are considered to be exogenously determined. This assumption implicitly entails a price taking behavior by commercial banks on the interbank money market and the customer deposits market. The official interest rate and the interest rate on excess reserves held in the central bank are set by the latter, who is the monopolistic supplier of the monetary base.

The model is stated as follows. The commercial bank's balance sheet satisfies that

$$
Q_{B / N B}+R_{\text {min }}+E R=Q_{C B / B}+Q_{\bar{B} / B}+D .
$$

The asset side is comprised by the amount of loans granted to the non-financial sector, and denoted as $Q_{B / N B}$, the level of minimum reserves $R_{\min }$ imposed by central banks as 
collateral - determined by a maintenance ratio $0<r<1$ - and the excess reserves $E R$ that commercial banks can hold in central banks as an investment. The liability side is given by three components. First, the credit obtained from the central bank, denoted as $Q_{C B / B}$. Second, the net loans obtained from the interbank money market, $Q_{\bar{B} / B}$, with $\bar{B}$ referring the rest of banks operating in the interbank money market. Third, commercial banks receive deposits, $D$, from customers. The balance sheet (1) provides banks a profit that is determined by the difference between the returns on the assets and the interest rate paid on the liabilities. To complete the model, we also contemplate the possibility that a share of the supplied loans defaults. This is modelled by the probability of default $p_{d}$. In this case, the bank earns a rate from selling the collateral asset. We impose in what follows a set of assumptions that allows us to derive a closed form expression for the optimal supply of loans by commercial banks.

\section{Assumptions:}

A.1: Banks are risk neutral.

A.2: $Q_{C B / B}=\lambda Q_{B / N B}$, with $0<\lambda \leq 1$.

A.3: $E R=\tau Q_{B / N B}$, with $0 \leq \tau<1$.

A.4: $p_{d}=\phi Q_{B / N B}$, with $0 \leq \phi<\frac{1}{Q_{B / N B}}$.

Assumption 1 entails a banking system of risk neutral individuals. This implies that banks maximize their profit function without any risk transformation. Assumption 2 implies that the amount of funds borrowed from the central bank is a fraction $\lambda$ of total lending. A value of this parameter smaller than one reflects constraints on the monetary base provided by the central bank. This is the case, for example, when the aggregate demand for credit by commercial banks is much higher than the monetary base targeted by the central bank, implying that each bank is only allocated a fraction of its total demand. Assumption 3 implies that only a fraction of total loan supply is left as remunerated deposits in the central bank. Assumption 4 implies that the default rate, is a function $\phi$ of the total supply of loans by the commercial bank. 
The bank's profit function is

$$
\Pi=i Q_{B / N B}+i_{r} R_{m i n}+\widetilde{i}_{r} E R-i_{r} Q_{C B / B}-i_{m} Q_{\bar{B} / B}-i_{d} D
$$

where $i$ denotes the gross return derived from loans to the non-financial sector, $i_{r}$ is the official policy rate, $\widetilde{i}_{r}$ is the gross return paid by the central bank to excess returns, $i_{m}$ is the interbank money market interest rate and $i_{d}$ is the interest rate paid on customer deposits. Under assumptions A.1-A.4 and the identity condition (1) that implies the condition

$$
Q_{\bar{B} / B}=Q_{B / N B}+R_{m i n}+E R-Q_{C B / B}-D
$$

the profit function (2) can be expressed as

$$
\Pi\left(Q_{B / N B}\right)=\left[\left(i-i_{m}\right)+\left(i_{m}-i_{r}\right) \lambda+\left(\widetilde{i}_{r}-i_{m}\right) \tau\right] Q_{B / N B}+\left(i_{r}-i_{m}\right) R_{m i n}+\left(i_{m}-i_{d}\right) D
$$

The variable $D$ and the interest rates $i_{m}, i_{r}, \tilde{i}_{r}$ and $i_{d}$ are exogenously given to the commercial bank. The quantity $Q_{B / N B}$ is the decision variable optimally chosen by the bank. The interest rate $i$ is a random variable that depends on the probability of default by borrowers. Hence, its expected value is $E[i]=i_{c}\left(1-p_{d}\right)+\widetilde{i}_{c} p_{d}$, with $i_{c}$ the interest rate on the share of loans that is repaid by borrowers and $\widetilde{i}_{c}$ the interest rate obtained from the collateral assets for the proportion of loans that default. In this scenario, the profit function $\Pi\left(Q_{B / N B}\right)$ is a random variable such that

$\left.E\left[\Pi \mid Q_{B / N B}\right]=\left[\left(i_{c}-i_{m}\right)+\widetilde{\left(i_{c}\right.}-i_{c}\right) \phi Q_{B / N B}+\left(i_{m}-i_{r}\right) \lambda+\left(\widetilde{i}_{r}-i_{m}\right) \tau\right] Q_{B / N B}+\left(i_{r}-i_{m}\right) R_{m i n}+\left(i_{m}-i_{d}\right) D$

Rearranging terms, we obtain

$E\left[\Pi \mid Q_{B / N B}\right]=\left[\left(i_{c}-i_{m}\right)+\left(i_{m}-i_{r}\right) \lambda+\left(\widetilde{i}_{r}-i_{m}\right) \tau\right] Q_{B / N B}+\left(\widetilde{i}_{c}-i_{c}\right) \phi Q_{B / N B}^{2}+\left(i_{r}-i_{m}\right) R_{m i n}+\left(i_{m}-i_{d}\right) D$ 
The optimal supply of loans by a commercial bank is the result of maximizing the objective function $E\left[\Pi \mid Q_{B / N B}\right]$ with respect to $Q_{B / N B}$. The first order condition of this problem that determines the optimal supply of credit by an arbitrary commercial bank in the system - is:

$$
Q_{B / N B}^{s 1}=\frac{\left.\left(i_{c}-i_{m}\right)+\left(i_{m}-i_{r}\right) \lambda+\widetilde{i}_{r}-i_{m}\right) \tau}{2 \phi\left(i_{c}-\widetilde{i}_{c}\right)} .
$$

In order to determine the credit interest rate in equilibrium we need to establish the corresponding demand schedule for loans from the non-financial sector. For simplicity, we consider this demand to depend on aggregate output $Y$ and to be perfectly inelastic with respect to the credit interest rate $^{2}$ :

$$
Q_{B / N B}^{d}=\alpha Y
$$

The assumption that there are $N$ homogeneous commercial banks entails the following equilibrium condition in the loan market:

$$
N Q_{B / N B}^{s 1}=Q_{B / N B}^{d}
$$

wich entails the following credit interest rate in equilibrium:

$$
i_{c}^{(1)}=\frac{\lambda i_{r}+(1-\lambda) i_{m}+\left(i_{m}-\widetilde{i}_{r}\right) \tau-2 \widetilde{i}_{c} \alpha Y \phi / N}{1-2 \alpha Y \phi / N} .
$$

This expression establishes that the loan market interest rate depends on the structure of the liability side of commercial banks' balance sheets. In particular, the parameter $\lambda$, denoting the proportion of banks' loans that is financed through the central bank, determines to a large extent the pass-through from the short-term policy rate to the equilibrium interest rate. In contrast, if $\lambda$ is close to zero the credit interest rate is mainly determined by the credit conditions in the interbank money market. Perfect competition in the credit market

\footnotetext{
${ }^{2}$ A similar assumption fixing loan demand is imposed by Dell'Ariccia et al. (2014) to analyze the case of a monopolist facing an inelastic demand function.
} 
$(N \rightarrow \infty)$ implies that

$$
i_{c}^{(1)}=\lambda i_{r}+(1-\lambda) i_{m}+\left(i_{m}-\widetilde{i}_{r}\right) \tau
$$

The equilibrium condition also reveals that the possibility of holding funds with the central bank as excess returns $(\tau>0)$ inflates the credit interest rate with respect to the policy rate $i_{r}$ and the interbank money market rate $i_{m}$.

Further, equation (10) allows us to derive a closed form expression for the spread between the credit interest rate and the short-term policy rate. Simple algebra shows that

$$
i_{c}^{(1)}-i_{r}=\frac{(1-\lambda)\left(i_{m}-i_{r}\right)+\left(i_{m}-\widetilde{i}_{r}\right) \tau-2\left(\widetilde{i}_{c}-i_{r}\right) \alpha Y \phi / N}{1-2 \alpha Y \phi / N} .
$$

This condition reinforces the findings discussed before. It is perhaps worth mentioning the effect of the spreads between the interest rate on the collateral and the policy rate $\left(\widetilde{i}_{c}-i_{r}\right)$ on the spread on the credit interest rate. A return on the collateral higher than the policy rate reduces the credit interest rate spread. This finding suggests that banks are more likely to reduce credit interest rates when the value of their collateral assets is high, such that they are able to recover a significant amount of the investment in case of loan default. This finding depends, however, on the type of competition in the market for loans.

\section{Optimal credit supply under the implementation of UMPs}

Our working hypothesis is that the implementation of UMPs by central banks increases the monetary base. The aim of these measures is to invigorate the balance sheet of commercial banks and, as a consequence, to restore the flow of credit to the non-financial sector. In this section, we derive the optimal supply of loans by commercial banks and the equilibrium interest rate under the implementation of two major unconventional monetary policies: the existence of lending facilities by the monetary authority and the creation of swap programmes that exchanged government bonds for the collateral held by commercial banks on toxic loans. 


\subsection{Central bank lending facilities}

The main objective of central bank lending facilities is to provide credit to the non-financial sector. Monetary authorities aim to do so by lending funds to commercial banks that are in turn used to restore the profitability of their portfolio of toxic assets (defaulted loans). This strategy results in an increase of the bank's balance sheet. In particular, the lending facilities imply a loan $L^{*}$ from the central bank to the commercial bank to cover the bank holdings of toxic assets derived from the defaulted loans. In this scenario the commercial bank's balance sheet satisfies that

$$
Q_{B / N B}+R_{\min }+E R+p_{d} Q_{B / N B}=Q_{C B / B}+Q_{\bar{B} / B}+D+L^{*}
$$

Given that the lending facilities are such that $L^{*}=p_{d} Q_{B / N B}$, the bank's profit function is

$$
\Pi\left(Q_{B / N B}\right)=i_{c} Q_{B / N B}+i_{r} R_{m i n}+\widetilde{i}_{r} E R-i_{r} Q_{C B / B}-i_{m} Q_{\bar{B} / B}-i_{d} D-i_{r} p_{d} Q_{B / N B}
$$

It is worth mentioning that, in contrast to the profit function (2) of the baseline model, the return on the loans supplied by the commercial bank is not uncertain. This is because the introduction of lending facilities implies that the bank is able to obtain a return of $i_{c}$ for the entire portfolio of loans. Using the identity provided by the balance sheet (13) and, more specifically, noting that $Q_{\bar{B} / B}=Q_{B / N B}+R_{\min }+E R-Q_{C B / B}-D$, we obtain:

$$
\Pi\left(Q_{B / N B}\right)=\left(i_{c}-i_{m}\right) Q_{B / N B}+\left(i_{r}-i_{m}\right) R_{m i n}+\left(\widetilde{i}_{r}-i_{m}\right) E R+\left(i_{m}-i_{r}\right) Q_{C B / B}+\left(i_{m}-i_{d}\right) D-i_{r} p_{d} Q_{B / N B}
$$

Under assumptions A.1-A.4, this profit function can be expressed as

$$
\Pi\left(Q_{B / N B}\right)=\left[\left(i_{c}-i_{m}\right)+\left(i_{m}-i_{r}\right) \lambda+\left(\widetilde{i}_{r}-i_{m}\right) \tau\right] Q_{B / N B}-i_{r} \phi Q_{B / N B}^{2}+\left(i_{r}-i_{m}\right) R_{m i n}+\left(i_{m}-i_{d}\right) D .
$$

The optimal supply of loans by a commercial bank under the presence of lending facilities, 
as those discussed above, is the result of maximizing this function with respect to $Q_{B / N B}$. The first order condition of this problem yields

$$
Q_{B / N B}^{s 2}=\frac{\left(i_{c}-i_{m}\right)+\left(i_{m}-i_{r}\right) \lambda+\left(\widetilde{i}_{r}-i_{m}\right) \tau}{2 \phi i_{r}}
$$

Using the same demand equation for loans from the non-financial sector, given by (8), and the presence of $N$ homogeneous commercial banks in the system, we achieve the following expression for the credit interest rate in equilibrium:

$$
i_{c}^{(2)}=\lambda i_{r}+(1-\lambda) i_{m}+\left(i_{m}-\widetilde{i}_{r}\right) \tau+2 i_{r} \phi \frac{\alpha Y}{N}
$$

Moreover, simple algebra allows us to obtain the spread with respect to the short-term policy rate:

$$
i_{c}^{(2)}-i_{r}=(1-\lambda)\left(i_{m}-i_{r}\right)+\left(i_{m}-\widetilde{i}_{r}\right) \tau+2 i_{r} \phi \frac{\alpha Y}{N} .
$$

This expression shows that the spread on the credit interest rate is driven by the risk premium on the interbank money market and the possibility of rewarding excess reserves on the central bank. There is an additional term that is determined by the degree of competition in the market for loans and the interest rate charged on the lending facilities. In the limiting case of perfect competition, the equilibrium interest rate (18) is the same of the baseline model. This finding suggests that lending facilities are not necessary to boost the credit market when there is strong competition in the market for loans.

The success of lending facilities in reducing the spread can be assessed through a comparison between the equilibrium credit interest rate in (18) and that obtained from inaction of the central bank, characterized by the baseline in (10). In doing so, we implicitly assume that the risk premium on the interbank money market and the parameters $\lambda, \tau$ and $\phi$ are all fixed and exogenously determined in the system. This comparison reveals that the implementation of lending facilities reduces the credit spread below that in the baseline 
scenario discussed in the previous section if

$$
\widetilde{i}_{c}<(1-\lambda)\left(i_{m}-i_{r}\right)+\left(i_{m}-\widetilde{i}_{r}\right) \tau+2 i_{r} f \frac{\alpha Y}{N} .
$$

This condition reflects the adequacy of lending facilities for reducing borrowing costs if the value of the collateral on defaulted loans is low and the risk premium on the interbank money market with respect to the interest rates set by the central bank is high.

Expression (20) is also useful for deriving a condition that determines the maximum amount of credit from the monetary authority that a commercial bank can borrow such that the implementation of lending facilities is still fruitful. More specifically, this condition is determined in terms of the parameter $\lambda$ that drives the variable $Q_{C B / B}$ :

$$
\lambda<1+\frac{\left(i_{m}-\widetilde{i}_{r}\right) \tau+\left(2 i_{r} \phi \frac{\alpha Y}{N}-\widetilde{i}_{c}\right)}{i_{m}-i_{r}} .
$$

A similar condition can be obtained with respect to the parameter $\tau$ determining the level of excess reserves.

\subsection{Government bond purchases}

The second UMP under scrutiny in the present paper is the implementation of swap programmes. These measures are characterized by the creation of monetary base by the central bank used to purchase government bonds that are exchanged for commercial banks' troubled assets. As in the previous scenario, we identify 'toxic' assets with defaulted loans and ignore the effects of swap programmes on other assets of the bank's balance sheet. Under

this scheme, commercial banks know that they can obtain an interest rate $i_{g}$ - instead of $\widetilde{i}_{c}$ - on their portfolio of defaulted loans $p_{d} Q_{B / N B}$.

In this scenario, in the event of bank's loan defaults, the balance sheet of the commercial bank becomes

$$
\left(1-p_{d}\right) Q_{B / N B}+G+R_{\min }+E R=Q_{C B / B}+Q_{\bar{B} / B}+D
$$


where $G=p_{d} Q_{B / N B}$ denotes the amount of government bonds swapped by the commercial bank in return for the portfolio of defaulted loans. In this case there is no expansion of the bank's balance sheet since the central bank absorbs the toxic assets. The corresponding bank's profit maximization problem is

$$
\Pi\left(Q_{B / N B}\right)=i_{c}\left(1-p_{d}\right) Q_{B / N B}+i_{g} G+i_{r} R_{m i n}+\widetilde{i}_{r} E R-i_{r} Q_{C B / B}-i_{m} Q_{\bar{B} / B}-i_{d} D
$$

Under assumptions A.1-A.4, the identity condition $G=p_{d} Q_{B / N B}$ and the balance sheet restriction (22) given by

$$
Q_{\bar{B} / B}=\left(1-p_{d}\right) Q_{B / N B}+G+R_{m i n}+E R-Q_{C B / B}-D
$$

entail the following profit function:

$\Pi\left(Q_{B / N B}\right)=\left[\left(i_{c}-i_{m}\right)\left(1-p_{d}\right)+\left(i_{g}-i_{m}\right) p_{d}+\left(i_{m}-i_{r}\right) \lambda+\left(\widetilde{i}_{r}-i_{m}\right) \tau\right] Q_{B / N B}+\left(i_{r}-i_{m}\right) R_{m i n}+\left(i_{m}-i_{d}\right) D$.

Further algebra shows that this function can be expressed as a quadratic function of $Q_{B / N B}$ as

$$
\left.\Pi\left(Q_{B / N B}\right)=\left[\left(i_{c}-i_{m}\right)+\left(i_{m}-i_{r}\right) \lambda+\widetilde{i_{r}}-i_{m}\right) \tau\right] Q_{B / N B}-\left(i_{c}-i_{g}\right) \phi Q_{B / N B}^{2}+\left(i_{r}-i_{m}\right) R_{m i n}+\left(i_{m}-i_{d}\right) D
$$

The optimal supply of loans by a commercial bank is the result of maximizing this function with respect to $Q_{B / N B}$. The first order condition of this problem yields

$$
Q_{B / N B}^{s 3}=\frac{\left.\left(i_{c}-i_{m}\right)+\left(i_{m}-i_{r}\right) \lambda+\widetilde{i}_{r}-i_{m}\right) \tau}{2 \phi\left(i_{c}-i_{g}\right)}
$$

In order to derive the credit interest rate in equilibrium, we aggregate the supply function over the $N$ banks in the system and consider the equibrium condition (9). The credit interest 
rate is

$$
i_{c}^{(3)}=\frac{\lambda i_{r}+(1-\lambda) i_{m}+\left(i_{m}-\widetilde{i}_{r}\right) \tau-2 \phi i_{g} \frac{\alpha Y}{N}}{1-2 \phi \frac{\alpha Y}{N}} .
$$

The corresponding spread over the short-term policy rate $i_{r}$ can be expressed as

$$
i_{c}^{(3)}-i_{r}=\frac{(1-\lambda)\left(i_{m}-i_{r}\right)+\left(i_{m}-\widetilde{i}_{r}\right) \tau-2\left(i_{g}-i_{r}\right) \phi \frac{\alpha Y}{N}}{1-2 \phi \frac{\alpha Y}{N}} .
$$

Interestingly, the spread on the credit interest rate is similar to the previous cases. In contrast to expressions (12) and (19), we find an additional term that is driven by the difference between the interest rate on government bonds and the policy short rate.

More generally, we can also establish the conditions that determine the relative success of this strategy with respect to the baseline model and the existence of lending facilities. Thus, the comparison of expressions (10) and (28) shows that swap programmes are successful in reducing borrowing costs when the interest rate on government bonds is higher than the return offered by the collateral assets held for defaulted loans. Meanwhile, the comparison of (18) and (28) reveals that the creation of lending facilities reduces the credit spread with respect to the counterpart spread under swap programmes if

$$
i_{g}<(1-\lambda)\left(i_{m}-i_{r}\right)+\left(i_{m}-\widetilde{i}_{r}\right) \tau+2 i_{r} \phi \frac{\alpha Y}{N} .
$$

This condition is similar to (20) and highlights the importance of the interbank market risk premium in determining credit conditions in the loan market. It also shows the negative influence that rewarding excess reserves by the central bank may have on borrowing costs. As we did in expression (21), equation (30) is also useful for determining the maximum amount of credit from the monetary authority that a commercial bank can borrow such that the implementation of swap programmes is still fruitful. In this case, we have

$$
\lambda<1+\frac{\left(i_{m}-\widetilde{i}_{r}\right) \tau+\left(2 i_{r} \phi \frac{\alpha Y}{N}-i_{g}\right)}{i_{m}-i_{r}} .
$$

A similar condition can be obtained with respect to the parameter $\tau$ determining the level 
of excess reserves.

\section{Quantitative model assessment}

This section reports a simulation exercise that illustrates the predictions of the theoretical model discussed above. The main goal is to analyze the supply of credit by commercial banks under the three scenarios described in the preceding sections.

To motivate this quantitative exercise, Figure 1 shows the differences in the dynamics of the official and credit interest rates for the United States (US) and the euro area (EA). The spreads between these interest rates in each economy are also reported. The graphs reveal the presence of upward and downward movements of the official interest rate. It is, however, surprising that the dynamics of the spreads for the US and the EA show different patterns in the wake of the 2007-2008 financial turmoil. Whereas the US credit spread decreases after the crisis to $3 \%$ and remains constant afterwards, the credit spread corresponding to the EA displays a significant increase in the aftermath of the crisis and follows an upward trend from 2010 onwards. This contrast in the dynamics of the interest rate spreads may be due to the differences in the implementation of UMPs across the two economic areas considered. While the US mainly embarked on exchange programmes to swap troubled assets for government bonds and other risk-free assets, the rescue packages of the EA mainly consisted of creating lending facilities that provided unlimited access to credit from the ECB to financial institutions.

\section{[Insert Figure 1 about here]}

We study the sensitivity of the conditions that characterize the relative performance across UMP measures to changes in model parameters. Their values have been chosen to suit data observed in the US and the EA during the period 2006-2012. With this aim, aggregate monetary and financial information for these economic areas have been extracted from the FRED database (St. Louis FED) and the ECB Statistical Data Warehouse. The description 
of the variables in our theoretical model and their simulation counterparts is reported in Tables 1 and 2 for the US and the EA, respectively.

\section{[Insert Tables 1 and 2 about here]}

As can be observed in Table 1, the short-term policy interest rate for the US is $2 \%$, excess reserves are considered to be rewarded at $0.25 \%$. Banks face a common loan default rate of $4 \%$ and the net return on the assets held as collateral is $2 \%$. While the fraction of total lending held as excess reserves in the FED is $2 \%$, the corresponding fraction borrowed by commercial banks from it is $3 \%$. Finally, we have chosen an interest rate in the interbank money market of $5 \%$ and a return on government bonds of $4 \%$.

Figure 2 compares the credit supply schedule in the baseline scenario (7) to those obtained when implementing UMPs (17) and (27). The sensitivity analysis considers shifts in the optimal loan supply due to increases in the interbank money market $\left(i_{m}=0.05\right.$, $0.06,0.07$; left panel) and in the fraction of total lending that is borrowed from the central bank $(\lambda=0.03,0.13,0.23$; right panel). The results show the outperformance of both UMPs with respect to the baseline in easing access to credit. More specifically, the charts in the left panel of Figure 2 confirm the success of lending facilities and swap programmes in reducing the credit spread for different values of the interbank money market rate. The bottom charts also show a general lower path of credit interest rates for the lending facilities programmes than for swap programmes. The right bottom panel suggests very similar performance of both measures with regards to the fraction of loans borrowed from the central bank. Interestingly, the convexity of the loan supply schedule for swap programmes suggests a more rapid increase of the credit interest rate with respect to the lending facilities scenario, implying a better performance of the latter for large values of the credit stock.

\section{[Insert Figure 2 about here]}


Figure 3 presents the results obtained from a similar analysis for the EA. As reported in Table 2, the initial values that characterize the baseline model in this case are a short-term policy rate of $3 \%$ and a reward for reserves in excess of the minimum maintenance ratio of $0.2 \%$. The common loan default rate is equal to $4 \%$ and the net return on the collateral for the non-performing assets is $2 \%$. The fraction of total lending held as excess reserves by commercial banks is $1 \%$, the interbank money market interest rate is $5 \%$ and the return on government bonds is equal to $4 \%$. Finally, the percentage of the total amount of loans that is borrowed from the ECB is $7 \%$.

The simulation exercise with European data yields similar results to those obtained for the US. The important difference in the amount of money borrowed from the central bank in these two economic areas is reflected in the bottom panels of Figure 3. These charts reveal the outperformance of swap programmes with respect to lending facilities for different choices of model parameters. The creation of lending facilities only displays a better performance than swap programmes for large values of the interbank money market rate and banks' credit supply. These findings highlight the close connection between the composition of the liability side of commercial banks' balance sheets, the credit stock and the optimal choice of the UMP to be implemented.

\section{[Insert Figure 3 about here]}

Figure 4 illustrates the relevance of conditions (21) and (31) for the US and EA banking sectors. Top panel corresponds to (21) while the bottom panel reflects the implications of (31). The top panels analyze the sensitivity of the first condition to an increase in the net return on the collateral from $2 \%$ (black solid line) to $3 \%$ (black dashed line). The results reported in these panels provide further support to the choice of lending facilities as a measure that is potentially able to reduce the credit interest rate in the US. The solid lines corresponding to condition (21) determine the values of $\lambda$ that are compatible with the success of lending facilities. These values increase with credit supply with a slope that 
depends positively on the short-term policy rate and the default rate, and negatively on the risk premium on the interbank money market. These results reflect earlier findings according to which higher values of the collateral reduce the success of lending facilities in decreasing the credit spread. In fact, for the US example, a $1 \%$ increase in the net return on the collateral assets implies a failure of this UMP in easing credit conditions.

The bottom panels show the sensitivity of (31) to a decrease in the return on government bonds from $4 \%$ (black solid line) to 3\% (black dashed line). The red solid lines correspond to the observed fraction of borrowing from the central bank in the US (3\%) and the EA (7\%), respectively. The analysis reported in these graphs reflects the outperformance of swap programmes over lending facilities for the observed value of $\lambda$ in the US, regardless the amount of credit supplied to the market. These results confirm the adequacy of swap programmes implemented by the FED during the recent financial crisis in reducing borrowing costs to the non-financial sector.

\section{[Insert Figure 4 about here]}

The simulation exercise with European data suggests a poor performance of lending facilities in reducing borrowing costs. In particular, condition (21) is violated for low values of credit supply if the return on the collateral is $2 \%$. A higher value of this parameter $(3 \%)$ results in stronger rejections of this UMP as a valid instrument for easing access to credit. Similarly, the graph at the bottom right of Figure 4 provides overwhelming evidence of the outperformance of swap programmes over lending facilities raising some doubts about the suitability of the lending facilities created by the ECB during recent crisis episodes.

\section{Concluding remarks}

This paper has proposed a simple theoretical framework to evaluate the success of the most important UMPs implemented by central banks during the recent crisis episodes. The spread between the credit interest rate and the short-term policy rate is determined by the 
risk premium in the interbank money market, the composition of commercial banks' balance sheets, the value of the assets held as collateral for defaulted loans and the default rate on the portfolio of loans. The degree of competition in the banking sector and the amount of excess reserves maintained in the central bank also play a key role in determining the credit interest rate in equilibrium.

The proposed model predicts that lending facilities are appropriate measures for reducing the credit interest rate when the assets held by banks as collateral lose their value and when the risk premium on the interbank money market is high. Similarly, the analysis of swap programmes predicts its success in reducing the credit interest rate if government bond yields are higher than the return provided by the collateral assets on defaulted loans. We have also compared the relative performance between these UMP measures. Our results show that lending facilities outperform swap programmes when the risk premium on the interbank money market is sizeable and the yield on government bonds is low and when the share of bank lending obtained from the central bank is not very large. More specifically, we observe that the greater the reliance of the banking sector on central bank lending during normal periods the more difficult it becomes for lending facilities to reduce the credit interest rate. Further, lending facilities will be a better alternative to reduce the credit interest rate when the return offered by the central bank on excess reserves and the default rate on loans are high.

This model can be extended to accommodate dynamics in the banks' profit function. It would be also of interest to analyze this problem within a general equilibrium model setup in which the interest rate on the interbank money market, the central bank policy rate and customer deposits are jointly determined in equilibrium. This approach is however left for future research. 


\section{References}

[1] Baltensperger, E., 1980. Alternative approaches to the theory of the banking firm. Journal of Monetary Economics 6(1), 1-37.

[2] Brei, M., L. Gambacorta and G. von Peter, 2013. Rescue packages and bank lending. Journal of Banking and Finance 37(2), 490-505.

[3] Borio, C. and P. Disyatat, 2010. Unconventional monetary policies: An appraisal. Manchester School 78(s1), 53-89.

[4] Christiano, L. and D. Ikeda, 2011. Government policy, credit markets and economic activity. NBER Working Paper No 17142.

[5] Cukierman, A., 2013. Monetary policy and institutions before, during, and after the global financial crisis. Journal of Financial Stability 9(3), 373-384.

[6] Cukierman, A., 2014. Euro-area and US banks behavior, and ECB-Fed monetary policies during the global financial crisis: A comparison. CEPR Discussion Paper No 10289.

[7] Dell'Ariccia, G., L. Laeven and R. Marquez, 2014. Real interest rates, leverage, and bank risk-taking. Journal of Economic Theory 149, 65-99.

[8] Durré, A. and H. Pill, 2012. Central bank balance sheets as policy tools. BIS Paper No $66 \mathrm{~m}$.

[9] Fungácová, Z., L. Solanko and L. Weill, 2014. Does competition influence the bank lending channel in the euro area? Journal of Banking and Finance 49, 356-366.

[10] Godlewski, C. J. and L. Weill, 2011. Does collateral help mitigate adverse selection? A cross-country analysis. Journal of Financial Services Research 40(1), 49-78.

[11] Joyce, M., D. Miles, A. Scott and D. Vayans, 2012. Quantitative easing and unconventional monetary policy - An introduction. Economic Journal 122, F271-F288. 
[12] Kiyotaki, N. and J. Moore, 2012. Liquidity, business cycles, and monetary policy. NBER Working Paper No 17934.

[13] Lenza, M., H. Pill and L. Reichlin, 2010. Monetary policy in exceptional times. Economic Policy 25(4), 297-339.

[14] Moore, J., 2009. Contagious illiquidity. Hurwicz Lecture, Latin American Meeting of the Econometric Society, Buenos Aires, Argentina.

[15] Niehans, J., 1978. The Theory of Money. The John Hopkins University Press.

[16] Orr, D. and W. G. Mellon, 1961. Stochastic reserve losses and expansion of bank credit. American Economic Review 51(4), 614-623.

[17] Reifschneider, D. and J. C. Williams, 2000. Three lessons for monetary policy in a low inflation era. Journal of Money, Credit and Banking 32(4), 936-966. 


\section{Tables and figures}

Table 1. Quantitative model assessment. Selection of the parameter values for the United States.

\begin{tabular}{|c|c|c|c|c|c|}
\hline Model & FRED database & 2006 & 2008 & 2012 & Simulations \\
\hline Official interest rate $\left(i_{r}\right)$ & Effective Federal Funds rate & 4.96 & 1.93 & 0.14 & 0.02 \\
\hline Interest rate paid on excess & Interest rate paid on excess reserve balances & 0.00 & 0.00 & 0.25 & $2.50 \mathrm{E}-03$ \\
\hline reserves $\left(\tilde{\imath}_{r}\right)$ & (2-week maintenance period) & & & & \\
\hline Interbank market rate $\left(i_{m}\right)$ & Interbank rates (3-month/90-day) & 1.56 & 2.97 & 0.28 & 0.05 \\
\hline \multirow[t]{2}{*}{ Net return on collateral $\left(\tilde{\imath}_{c}\right)$} & Bank prime loan rate*Percentage of value of & 5.20 & 3.12 & 2.33 & 0.02 \\
\hline & loans secured by collateral & & & & \\
\hline Government bonds rate $\left(i_{g}\right)$ & 10-year Treasury constant maturity rate & 4.80 & 3.66 & 1.80 & 0.04 \\
\hline Fraction of total lending held as & Excess reserves of depository institutions as & 0.02 & 1.53 & 15.16 & 0.02 \\
\hline excess reserves $(\tau)$ & a percentage of credit (all commercial banks) & & & & \\
\hline Fraction of total lending borrowed & Credit over total borrowing of depository & $2.94 \mathrm{E}-03$ & 3.01 & 0.05 & 0.03 \\
\hline from the central bank $(\lambda)$ & institutions from the FED & & & & \\
\hline Loan probability of default $(\phi)$ & Loan delinquency rate (all commercial banks) & 1.57 & 3.67 & 5.02 & 0.04 \\
\hline
\end{tabular}


Table 2. Quantitative model assessment. Selection of the parameter values for the euro area.

\begin{tabular}{|c|c|c|c|c|c|}
\hline Model & ECB Statistical Data Warehouse & 2006 & 2008 & 2012 & Simulations \\
\hline Official interest rate $\left(i_{r}\right)$ & Interest rate for main refinancing operations & 3.00 & 3.71 & 0.75 & 0.03 \\
\hline Interest rate paid on excess & Interest rate for deposit facility & 2.00 & 2.87 & 0.00 & 0.02 \\
\hline \multicolumn{6}{|l|}{ reserves $\left(\tilde{\imath}_{r}\right)$} \\
\hline Interbank market rate $\left(i_{m}\right)$ & Euribor (3-month) & 3.08 & 4.64 & 0.57 & 0.05 \\
\hline \multirow[t]{2}{*}{ Net return on collateral $\left(\tilde{\imath}_{c}\right)$} & Interest rate for loans $(<1 \text { year })^{*}$ Percentage of & 4.50 & 4.91 & 3.19 & 0.03 \\
\hline & loand with collateral (Godlewski and Weill, 2011) & & & & \\
\hline Government bonds rate $\left(i_{g}\right)$ & Spot rate (all ratings), 10-year maturity & 3.98 & 3.92 & 3.01 & 0.04 \\
\hline Fraction of total lending held as & Excess reserve maintenance by credit institutions & 0.01 & 0.01 & 3.31 & 0.01 \\
\hline excess reserves $(\tau)$ & as a percentage of their loans to non-MFIs & & & & \\
\hline Fraction of total lending borrowed & ECB lending to credit institutions as a percentage & 4.52 & 7.16 & 9.24 & 0.07 \\
\hline from the central bank $(\lambda)$ & of their loans to non-MFIs & & & & \\
\hline Loan probability of default $(\phi)$ & Percentage of doubtful and non-performing loans & $2.93^{*}$ & 2.54 & 5.32 & 0.04 \\
\hline
\end{tabular}

Note: ${ }^{*}$ data for the year 2007 . 

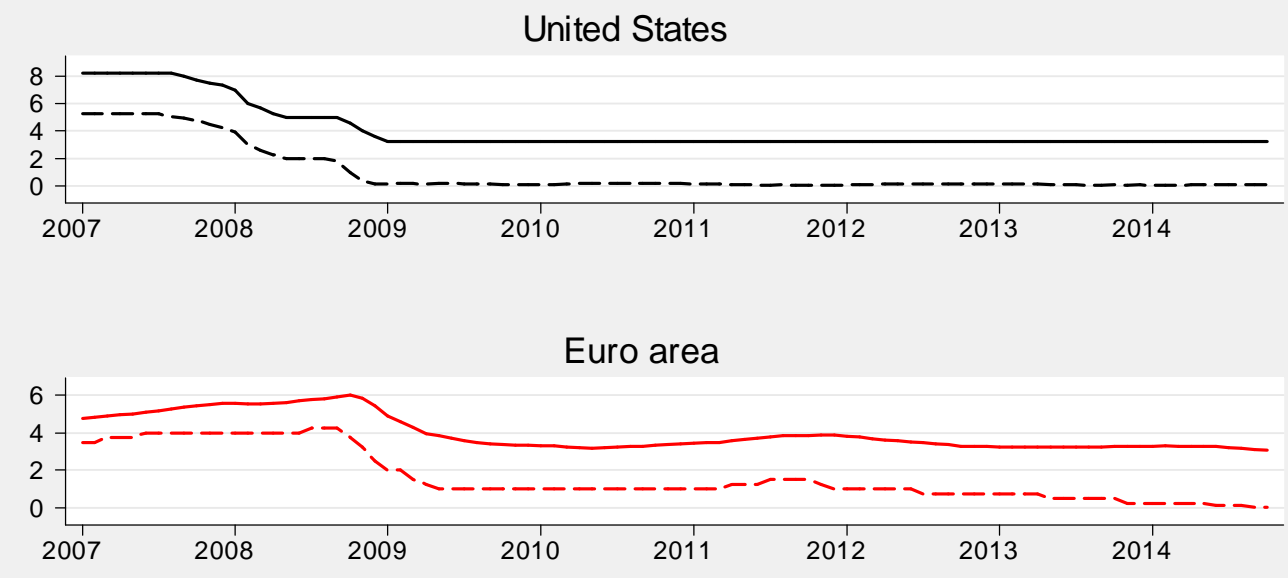

Spreads

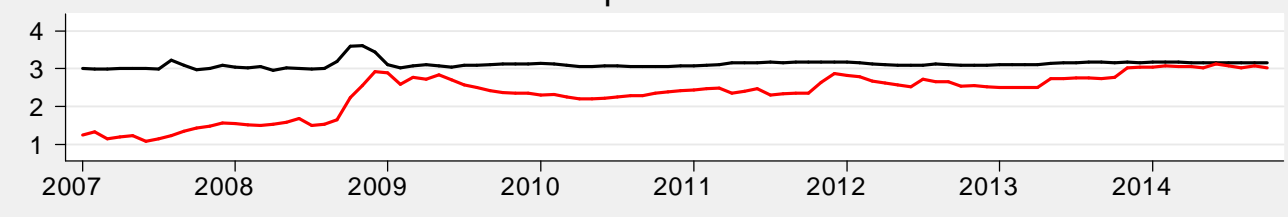

Figure 1: Credit (solid) and short-term policy (dashed) rates, 2007:01-2014:10. 
(a) Interbank rate $\left(i_{m}\right)$

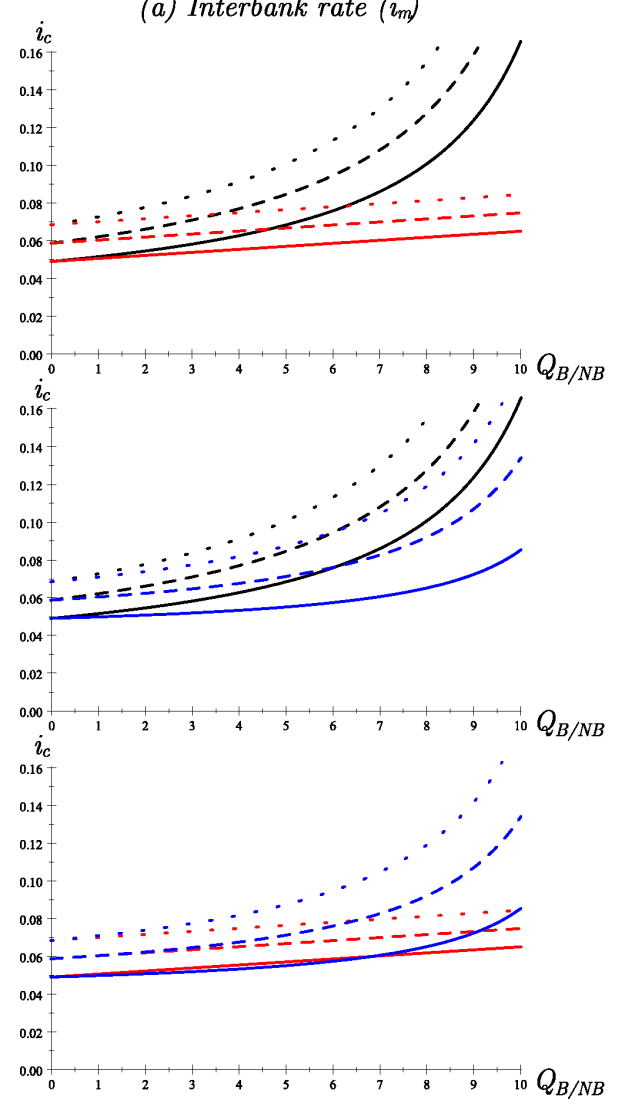

(b) Credit from central bank $(\lambda)$

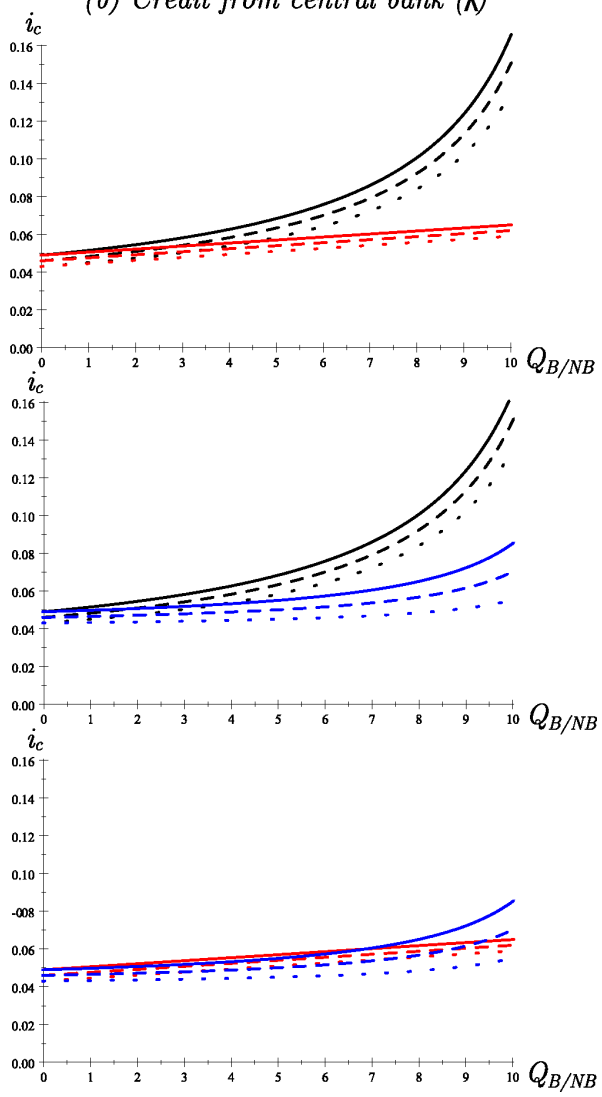

Figure 2: Credit supply curves: Baseline (black), lending facilities (red) and swap programmes (blue) scenarios. Effects of increases in model parameters (solid to dotted) fitting US data (see Table 1). 

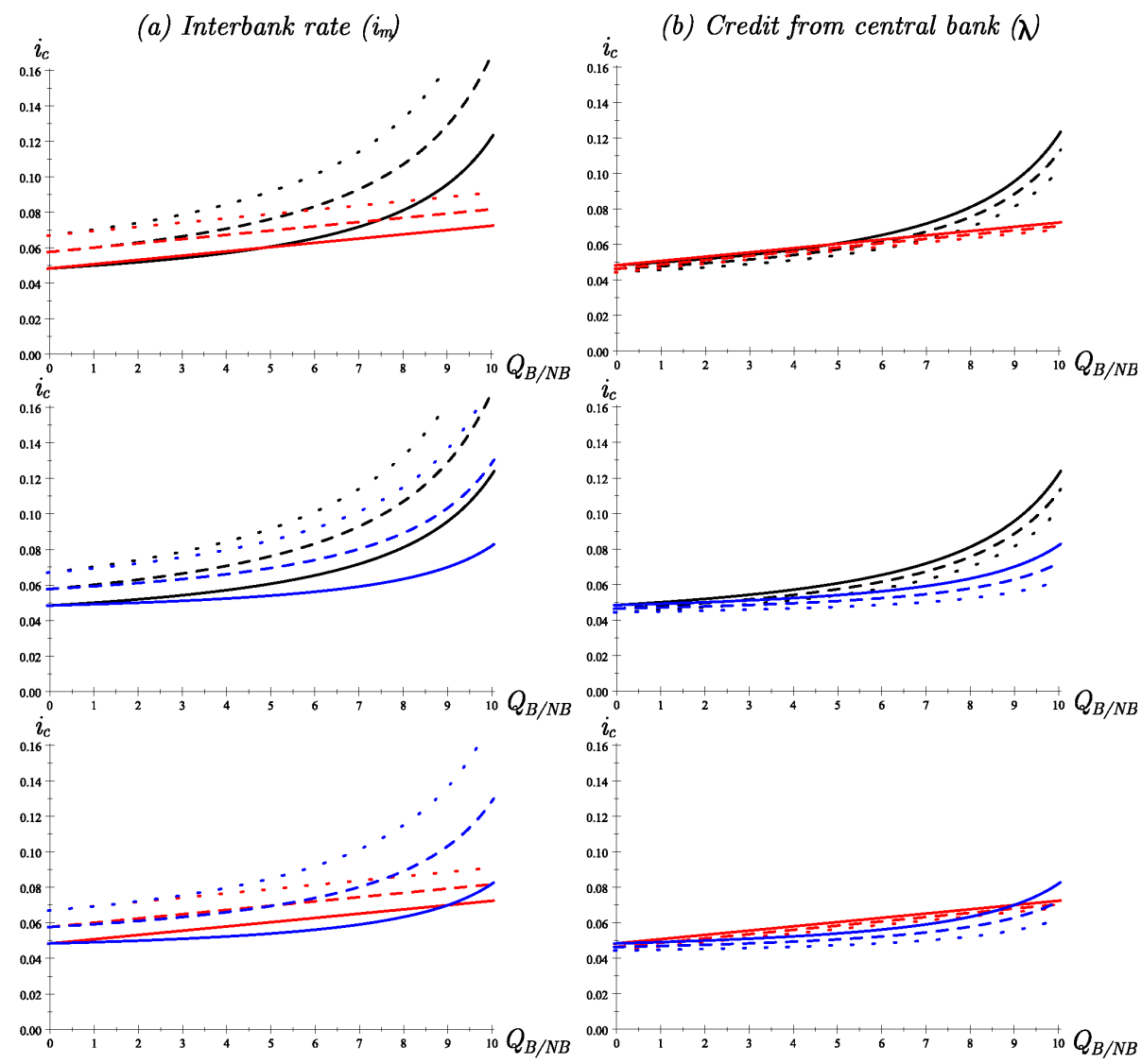

Figure 3: Credit supply curves: Baseline (black), lending facilities (red) and swap programmes (blue) scenarios. Effects of increases in model parameters (solid to dotted) fitting EA data (see Table 2). 
(a) United States

(a.1) Lending facilities vs. baseline

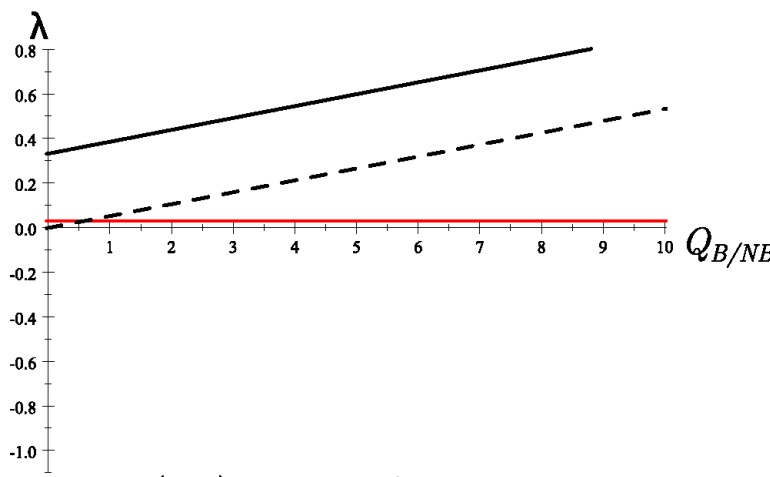

(a.2) Lending facilities vs.

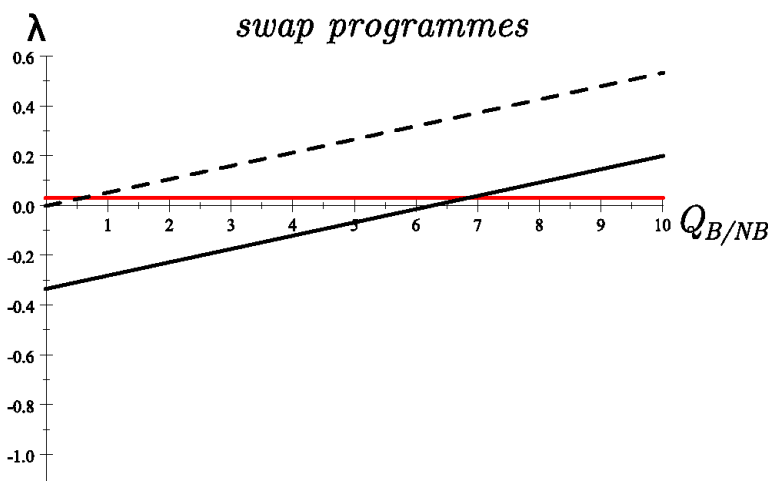

(b) Euro area

(b.1) Lending facilities vs. baseline

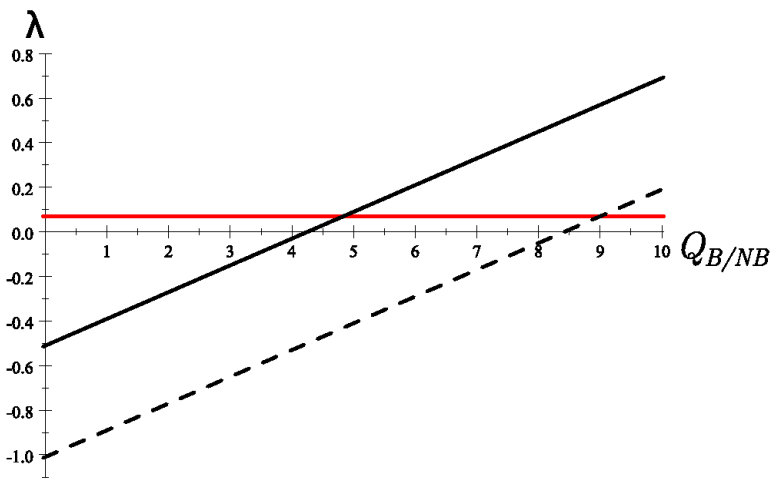

(b.2) Lending facilities vs. swap programmes

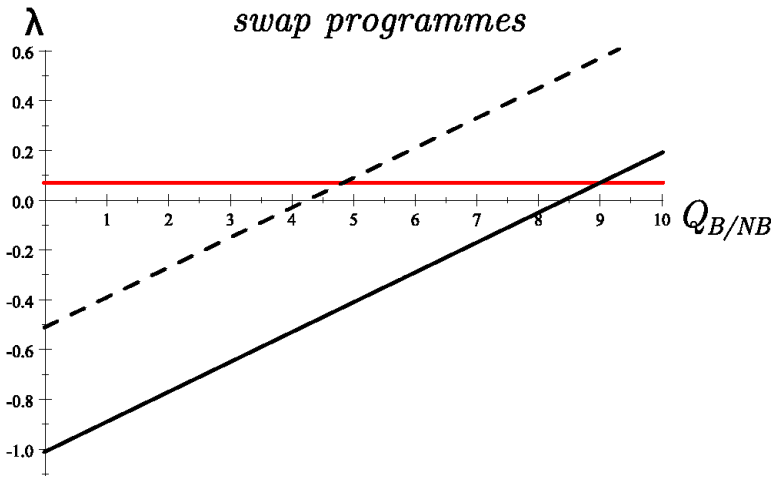

Figure 4: Relative policy effectiveness. The areas below the black lines correspond to a better performance of lending facilities in reducing the credit interest rate. Red horizontal lines are the observed values for the percentage of commercial bank loans that are borrowed from the monetary authority. Dashed lines in the upper (lower) panel reflect an increase (decrease) in the net return on the collateral (government bonds rate). 


\section{Appendix}

Table A1. Parameters included in the theoretical framework.

\begin{tabular}{|c|c|}
\hline Parameter & Variable \\
\hline$N$ & Number of commercial banks in the system \\
\hline$Q_{B / N B}$ & Amount of loans granted by commercial banks to the non-financial sector \\
\hline$Q_{C B / B}$ & Credit obtained by commercial banks from the central bank \\
\hline$\lambda$ & Fraction of commercial banks' total lending borrowed from the central bank \\
\hline$Q_{\bar{B} / B}$ & Net loans from the interbank money market \\
\hline$D$ & Deposits held by customers in commercial banks \\
\hline$R_{\min }$ & Level of minimum reserves imposed by the central bank as collateral \\
\hline$r$ & Minimum reserves maintenance ratio \\
\hline$E R$ & Excess reserves held in the central bank \\
\hline$\tau$ & Fraction of commercial banks' total lending held as excess reserves \\
\hline$p_{d}$ & Loan probability of default \\
\hline$\phi$ & Relationship between the probability of default and the total amount of loans \\
\hline$i$ & Gross return from loans to the non-financial sector \\
\hline$i_{r}$ & Official interest rate \\
\hline$\tilde{\imath}_{r}$ & Gross return paid by the central bank to excess reserves \\
\hline$i_{m}$ & Interbank money market interest rate \\
\hline$i_{d}$ & Interest rate paid on customer deposits \\
\hline$i_{c}$ & Interest rate on the share of loans that is repaid by borrowers \\
\hline$\tilde{\imath}_{c}$ & Interest rate obtained from the collateral assets for the proportion of loans that default \\
\hline$i_{g}$ & Government bonds interest rate \\
\hline$Y$ & Aggregate output \\
\hline$L^{*}$ & Loan from the central bank under lending facilities \\
\hline$G$ & Amount of government bonds swapped for the portfolio of defaulted loans \\
\hline
\end{tabular}

